peared to be a compromise measure, for it was by no means free from all the ambiguities and possible divergent interpretations which have been discussed. However, the House of Representatives, when it took the proposal under consideration, materially strengthened it and carried it much further. It passed a bill to amend section 24 (a) by adding a new paragraph, to wit: "[In computing net income no deduction shall in any case be allowed in respect of - ] . . . Any amount otherwise allowable as a deduction under $\S 23$ (a) or $\S 23$ (a) (1) with respect to wearing apparel (including umiforms and work clothes), but this paragraph shall not prevent the allowance of a deduction to an employer with respect to such apparel furnished to an employee; ...." In the accompanying committee report ${ }^{48}$ it is stated: "The cost of safety equipment or other appliances would continue to be deductible as a business expense to the extent provided by present law."

It seems clear that if enacted into law this provision will not only eliminate the problem of deciding when work clothing "replaces" regular clothing, but will flatly disallow all clothing deductions except as to articles that can be brought within the category of safety equipment. The result presumably would be that the cost of such items as helmets and rubber boots for firemen and policemen would continue to be deductible, with a possible question mark as to the situation presented in the Clark case, ${ }^{49}$ where a deduction was allowed for work clothes which had to be changed daily to avoid the hazard of becoming saturated with oil and catching in the plant machinery. On the other hand, since "safety" rather than "replacement" would now be the key word in determining whether or not a deduction could be taken, even such Bureau-sanctioned deductions as theater costumes and jockeys' and baseball players' uniforms could no longer be allowed without stretching the law beyond all recognition.

It is believed that the proposed law would, if supplemented by precise and detailed Treasury Regulations, effect the most practicable and, under the circumstances, equitable solution possible.

\title{
MOTION TO DISMISS: USE OUTSIDE OF STATUTORY PROVISIONS: RELATION TO SUMMARY JUDGMENTS
}

California Code of Civil Procedure sections 581(3), 581(4), 581a, $581 \mathrm{~b}$, and 583 set forth the primcipal situations in which an action may be dismissed on motion of the defendant. ${ }^{1}$ There are also several

18 H. R. REP. No. 2087, 80th Cong., 2nd Sess. (1948).

49 See note 29 stupra.

1 These provide for a dismissal in the following situations: $\$ 581(3)$-if either party fails to appear at the trial, or if a demurrer to the complaint has been sustained and the plaintiff fails to amend; $\S 581(4)$-if the plaintiff abandons his case; $\S 581 a-i f$ the 
other code provisions which, without expressly providing for the use of a motion to dismiss, allow a court to dismiss a civil action. ${ }^{2}$ Such an elaborate statutory scheme might be thought to be exclusive. However, the California courts hold that they have inherent power to dismiss actions in situations not covered by the codes. ${ }^{3}$ The purpose of this comment is to examine the situations in which this loosely defined power has been exercised and the desirability of such procedure.

For a number of years there were no code provisions allowing dismissal for failure to prosecute with reasonable diligence, but, exercising inherent common law power, the courts recognized such a ground for a motion to dismiss. ${ }^{4}$ By 1905 a series of amendments and additions to the code had partially codified this power and placed certain time restrictions on its exercise. ${ }^{5}$ These rules now appear in sections 581a and 583 of the Code of Civil Procedure. Section 581a sets maximum time limits of one year in which a plaintiff may have a summons issued and three years in which he may have the summons served or a default judgment entered after service if defendant fails to answer. These limits are mandatory and the court appears to have no discretion after this time, but must dismiss the action. ${ }^{6}$ Section 583 allows dismissal for failure to bring the action to trial within two years after its commencement, ${ }^{7}$ and requires the court to dismiss after a lapse of five years. It further provides a maximum of three years within which plaintiff may bring the action to trial after a motion for a new trial has been granted or after reversal on appeal. ${ }^{8}$

The courts, however, still have maintained their right to dismiss

plaintiff fails within specified periods of time to have a summons issued or served, or fails to get a judgment entered when the defendant defaults; $\S 581 \mathrm{~b}-$ if an action is commenced in the wrong court and is ordered transferred and the plaintiff fails to pay the costs of this transfer within one year; $\$ 583$-if the plaintiff fails within specified periods of time to bring an action to trial, or to bring to trial after the granting of a motion for a new trial or after the reversal of a judgment for the defendant and remanding for a new trial. Formerly $\$ 581(5)$ provided for a motion to dismiss when the plaintiff failed to prove a sufficient case at the trial. In 1947 the Legislature deleted this and passed \$581c which allows this procedure under the name of nonsuit, a term the courts have applied for some time.

2 Cal. Code Crv. Proc. $\S \S 396 a, 594,1030,1184 a, 1190$, and 1282; Cat. Gen. Laws (Deering's) \$8474; CaL. Prob. Code § 1101 ; CaL. Erection Code $\$ 8555$.

${ }^{3}$ It has been contended that section 582 , which provides that "In all other cases judgment shall be rendered on the merits," confines the use of a motion to dismiss to the situations descrihed in the sections immediately preceding it, but the court has rcjected this argument. Johnston v. Baker (1914) 167 Cal. 260, 263, 139 Pac. 86, 88.

4 Johnston v. Baker, supra note 3; Romero v. Snyder (1914) 167 Cal. 216, 138 Pac. 1002 ; People v. Jefferds (1899) 126 Cal. 296, 58 Pac. 704.

5 For the legislative history of these additions see Johnston v. Baker, supra note 3.

6 Lieb v. Lager (1935) 9 Cal. App. (2d) $324,326,49$ P. (2d) $886,887$.

7 This minimum limit of two years prohibits a court from dismissimg prior to this. Johnston v. Baker, supra note 3 ; Romero v. Snyder, supra note 4; Jackson v. Thompsọn (1941) 47 Cal. App. (2d) 405, 118 P. (2d) 31.

8 After these maximum periods the court must dismiss the action. Christin v. Superior Court (1937) 9 Cal. (2d) 526, 71 P. (2d) 205. 
for failure to prosecute with reasonable diligence in situations not covered by this codification. ${ }^{9}$ For example, while section 581a requires a dismissal if the summons is not served and a return made within three years after the action is commenced, the section does not prevent a dismissal prior to this if the court in its discretion feels that the plaintiff has not prosecuted with reasonable diligence $;^{10}$ and, while section 581a does not cover the prosecution of cross-claims, nevertheless, a court has discretion to dismiss a cross-claim for failure to prosecute. ${ }^{11}$

Another use of the motion is to challenge the court's jurisdiction over the cause of action. If a court determines that it has no jurisdiction, it must dismiss the action. ${ }^{12}$ However, a dismissal for this reason is subject to the limitation of section 396 of the Code of Civil Procedure, which provides that if there is a court of the state that does have jurisdiction the action shall be transferred and not dismissed. Although section 396 will cover most cases, it is an implied recognition of a power to dismiss in situations not within it.

In Cunha v. Anglo California National Bank $k^{13}$ a third use of the motion to dismiss was recognized: to raise the question of whether an action was fictitious or sham. In this case both general and special demurrers to the complaint were sustained. The plaintiff filed two amended complaints, but in neither was he able to cure the defects. The defects had also been pointed out in an answer to the complaint. With the denurrers to the second amended complaint, the defendant moved to dismiss on the ground that the action was sham. This motion was supported by an affidavit of facts showing that the plaintiff had no cause of action. No counter-affidavits were filed by the plaintiff. The trial court sustained the demurrers without leave to amend and granted the motion to dismiss. The district court of appeals affirmed the ruling on the ground that the court had inherent power to prevent vexatious suits.

Still another use of a motion to dismiss has recently been permitted: to raise the issue of res judicata. In Olwell v. Hopkins ${ }^{14}$ plaintiff,

9 Johnston v. Baker, supra note 3 ; Romero v. Snyder, supra note 4.

10 Lieb v. Lager, supra note 6 . Accord, as to the 3 year maximum provided in section 583 for bringing a new trial when the plaintiff has obtained a reversal of judgment against him on the first trial: Inderbitzen v. Lane Hospital (1936) 17 Cal. App. (2d) 103, 61 P. (2d) 514. 854.

11 Fox Woodsum Lumber Co. v. Janes (1946) 76 Cal. App. (2d) 748, 173 P. (2d)

12 Rogers v. Cady (1894) 104 Cal. 288, 38 Pac. 81; Fritts v. Camp (1892) 94 Cal. 393, 29 Pac. 867; Heffron v. Vaughn (1944) 66 Cal. App. (2d) 161, 152 P. (2d) 23; Estate of Palmieri (1932) 120 Cal. App. 698, 8 P. (2d) 152. See also Ferryboatmen's Union v. Southem Pac. Co. (1935) 79 Cal. App. Dec. 796, 38 P. (2d) 425, hearing granted by Cahifornia Supreme Court but apparently never heard.

13 (1939) 34 Cal. App. (2d) 383, 93 P. (2d) 572, hearing denied by supreme court.

14 (1946) 28 Cal. (2d) 147, 168 P. (2d) 972. 
a foreign corporation, had formerly brought a suit on a contract. That action was dismissed because the corporation had not qualified to do busmess in California at the time the contract was made and thus the contract was void. In this suit on the same contract the former suit was noted in the complaint. The trial court, after a hearing in which the record of the first action was allowed to be submitted as evidence, sustamed the demurrer to the complaint without leave to amend and granted the defendant's motion to dismiss on the ground that the action was barred by the former judgment. Normally in ruling on a demurrer the court is restricted to what appears on the face of the complaint. ${ }^{15}$ The California Supreme Court, however, affirmed this decision over the plaintiff's objection that the defense of res judicata could not be raised by demurrer and motion to dismiss but only by answer. ${ }^{16}$ Apparently this conclusion was reached, not because this was a proper way to raise the issue, but because there would be no useful purpose in reversing since the former suit would still act as a bar. ${ }^{17}$

While these non-statutory uses of the dismissal procedure may seem reasonable enough, caution must be exercised in their extension. Contrary to the rule in some jurisdictions, ${ }^{18}$ in California a motion to dismiss can be supported by affidavits, ${ }^{19}$ and such motions are often heard and decided by the court on conflicting affidavits. ${ }^{20}$ The procedure seems to be to file a general demurrer and a motion to dismiss supported by affidavits or other evidence..$^{21}$ The court may then sustain the demurrer without leave to amend and grant the motion to

15 Lord v. Garland (1946) 27 Cal. (2d) 840,168 P. (2d) 5 .

16 Best v. Fitzgerald (1947) 81 A. C. A. 1129, 185 P. (2d) 377. Contra: Forrester v. Lawler (1910) 14 Cal. App. 170, 111 Pac. 284.

17 If the issue had heen raised by answer, section 597 of the Code of Civil Procedure would have provided for a hearing similar to the one given here. The court also uses this as a ground for refusal to reverse.

Other situations in which the use of a motion to dismiss bas been occasionally permitted are where the case has become moot, Honan v. Title Insurance etc. Co. (1935) 9 Cal. App. (2d) 675,50 P. (2d) 1068; where the attorney acting for the plaintiff has no authority from that party to hring a suit, People v. Madden (1901) 133 Cal. 347, 65 Pac. 741 ; Ventura County v. Clay (1897) 119 Cal. 213, 51 Pac. 189; Clark v. Willett (1868) $35 \mathrm{Cal} .534$; Turner v. Caruthers (1861) $17 \mathrm{Cal} .431$; and where one party to the action has died and the action does not survive him, Blodgett v. Greenfield (1929) $101 \mathrm{CaI}$. App. 399, 281 Pac. 694 (libel action).

18 Cases collected in 27 C. J.S. 249.

19 Guardianship of Van Loan (1904) 142 Cal. 423, 76 Pac. 37; California Etc. Bank v. Graves (1900) 129 Cal. 649, 62 Pac. 259; Cunha v. Anglo California Nat. Bank, supra note 13; Fuller v. Lindenbaum (1938) 29 Cal. App. (2d) 227, 84 P. (2d) 155; CAI. CoDE Crv. Proc. $\$ 2009$.

20 E.g., Hibernia Sav. \& Loan Soc. v. Lauffer (1940) 41 Cal. App. (2d) 725, 107 P. (2d) 494; Jackson v. De Benedetti (1940) 39 Cal. App. (2d) 574, 103 P. (2d) 990; Lieb v. Lager, supra note 6 .

21 E.g., Olwell v. Hopkins, supra note 14; Best v. Fitzgerald, supra note 16; Cunha v. Anglo California Nat. Bank, supra note 13. 
dismiss. ${ }^{22}$ Thus, in effect, it seems that the courts are using the affidavits, often conflicting, to rule on the demurrer. The danger thus arises that issues of fact on the merits of a case will be tried on affidavits. ${ }^{23}$

This use of the motion to dismiss supported by affidavits resembles the procedure provided for a motion for summary judgment, ${ }^{24}$ while lacking the safeguards present there. To procure a trial on the facts under the summary judgment procedure the opposing party need merely submit counter-affidavits sufficient to present a triable issue of fact. The court is not to decide the case on conflicting affidavits or to determine facts from them. The affidavits filed on behalf of the opponent to the motion are to be liberally construed. ${ }^{26}$ Since these restrictions do not apply to the motion to dismiss, there is danger that the opposing party will be deprived of a trial on the merits. ${ }^{27}$

The use of a motion to dismiss in situations not provided for in

22 Cases cited in note 21 supra. Section 581(3) allows a motion to dismiss if a demurrer to a complaint has been sustained and the plaintiff fails to amend in the time allowed by the court. This seems to be the only statutory procedure by which a defendant can get a judgment after his demurrer is sustained. However, the courts have allowed judgments on such a ruling without a motion to dismiss. E.g., Blumen v. Clayburgh (1935) 10 Cal. App. (2d) 63, 51 P. (2d) 102; Cruse v. Grubbs (1932) $121 \mathrm{Cal}$. App. 554, 9 P. (2d) 520.

23 This, in effect, circumvents the rule against speaking demurrers, as expressed in: Willson v. Security-First Nat. Bk. (1943) 21 Cal. (2d) 705, 134 P. (2d) 800; National Auto. Ins. Co. v. Winter (1943) 58 Cal. App. (2d) 11, 136 P. (2d) 22; MacKay v. Clark Rig Bldg. Co. (1935) 5 Cal. App. (2d) 44, 42 P. (2d) 341.

24 Car. Code Crv. Proc. \$ 437c.

25 Arnold v. Hibernia S. \& L. Soc. (1944) 23 Cal. (2d) 741, 146 P. (2d) 684; Eagle Oil \& Ref. Co. v. Prentice (1942) 19 Cal. (2d) 553, 122 P. (2d) 264; Walsh v. Walsh (1941) 18 Cal. (2d) 439, 116 P. (2d) 62.

${ }^{26}$ Aruold v. Hibernia S. \& L. Soc.; Eagle Oil \& Ref. Co. v. Prentice, both supra note 25 ; (1940) 13 So. CALIF. L. REv. 523 . "Because the procedure is summary and presented on affidavits without the benefit of cross-examination, a trial by jury and opportunity to observe the demeanor of witnesses in giving their testimony, the affidavits filed on behalf of the defendant should be liberally construed to the end that he will not be summarily deprived of the full hearing available at a trial of the action and the rigbts incident thereto. The procedure is drastic and should be used with caution in order that it may not become a substitute for existing methods in the determination of issues of fact." Eagle Oil \& Ref. Co. v. Prentice, supra note 25 at 556, 122 P. (2d) at 265.

$2 \pi$ A similar situation has arisen under Federal Rule $12(b)(6)$ which deals with a motion raising the defense that the complaint fails to state a claim upon which relief can be granted. Under this rule a lack of uniformity developed in the district courts, some allowing affidavits to be used im support of the motion and others feeling that this was not a proper procedure as it would be a speaking demurrer. In the Advisory Committee Report recommending an amendment of this rule to permit the admission of such matters outside the pleadings, the Committee advised that it be treated as a summary judginent. Advisory Committee Report (1946) 5 F. R.D. 433, 441, 442. It stated, "The Committee emphasizes particularly the fact that the summary judgment rule does not permit a case to be disposed of by judgment on the merits on affidavits, which disclose a conflict on a material issue of fact, and unless this practice is tied to the summary judgment rule, the extent to which a court, on the introduction of such extraneous matter, may resolve questions of fact on conflicting proof would be left uncertain." Id. at 443. This amendment was adopted by Congress and became effective on March 20, 1948. 